\title{
Millet Cobs: A Source of Microbial Enzymes
}

\author{
Arogunjo AO* and Arotupin DJ \\ Department of Microbiology, Federal University of Technology, Akure, Nigeria
}

\begin{abstract}
Microbial enzymes have significant biotechnological application in industries. The purpose of this study was to isolate and identify microorganisms associated with millet cobs, determine the enzyme activity (lipase, protease, pectinase, cellulase and amylase) of the millet cob samples, screen the isolated microorganisms for enzyme production and determine the physicochemical parameters of the degrading medium. A total of seven bacteria and twelve fungi consisting of yeasts and moulds were isolated during the study. Day 20 of the degradation period has the highest enzyme activity for all the enzymes in the degraded millet cobs; lipase has the highest enzyme activity with a value of $0.496 \mathrm{mg} / \mathrm{mL} / \mathrm{min}$ while protease has the lowest with a value of $0.003 \mathrm{mg} / \mathrm{mL} / \mathrm{min}$. All of the isolated microorganisms exhibited enzymatic activity except Zygosaccharomyces rouxii in which Bacillus spp were screened positive for all the enzymes assayed for. The temperature $\left({ }^{\circ} \mathrm{C}\right), \mathrm{pH}$ and titratable acidity $(\%)$ ranged from $24.03-$ $28.47,3.81-6.50$ and $2.31-4.21$ respectively. This study contributes to catalogue of microorganisms that has been identified as enzyme producers and provides additional information to support future research about the industrial potential of these microorganisms that may produce enzymes and other metabolites of industrial importance.
\end{abstract}

Keywords: Millet cobs; Enzymes; Bacteria; Fungi; pH, Temperature

\section{Introduction}

Many microorganisms such as bacteria, mould, and yeast produce a collection of multipurpose enzymes with extensive diversity of structures and industrial applications. Many microbial enzymes, such as amylases, cellulases, lipases, pectinases and proteases extracellularly produced. Amylases, starch-degrading enzymes, have numerous biotechnogical applications. These enzymes are used in textile and garments, paper industries, starch liquefaction, food, adhesive and sugar production and pharmaceuticals [1]. Cellulases, sugar degrading enzymes are used in textile industry for bio-polishing of fabrics and producing stonewashed look of denims, as well as in household laundry detergents for improving fabric softness and brightness [2]. Besides, they are used in animal feeds for improving the nutritional quality and digestibility, in processing of fruit juice and in baking, while de-inking of paper is yet another emerging application [3]. Lipases, lipid degrading enzyme are versatile tool for biotechnology. It is applicable in multiple industries such as agrochemical, pharmaceutical, cosmetic and perfume, taste and flavor industries, textile, food and dairy, detergent and surfactant industries, fat and oil, leather and paper production, chemical and waste water treatment [4]. Especially lipases are applied for biodiesel production [5]. Pectinases a group of enzymes that contribute to the degradation of pectin by various mechanisms. Acidic pectic enzymes are widely used in the production and clarification of fruit juices and wines [6]. They are also very important in maceration and solubilization of fruit pulps. Alkaline pectic enzymes have been used in several areas, including retting and degumming of fiber crops, textile processing, coffee and tea fermentations, paper and pulp industry, and oil extraction [7]. Proteases, enzyme which catabolizes protein by hydrolysis of peptide bonds are generally used in detergents, food industries meat processing, cheese making, silver recovery from photographic film, production of digestive and certain medical treatments of inflammation and virulent wounds [8-10]. They also have medical pharmaceutical applications [9]. The increase in world enzyme demand has led to sourcing for alternative substrate for the production of microbial enzyme; hence, agricultural wastes are readily accessible around the world as residual wastes for the production of these enzymes. In Nigeria, the most abundant renewable biomass resources include crop residues, such as corn straw, millet cobs, cassava peels, yam peels and rice husks.
Millets are a group of highly variable small seeded grasses, widely grown around the world as cereal crops or grains for fodder and human food. They do not form a taxonomic group, but rather a functional or agronomic one. Millets are important crops in the semi-arid tropics of Asia and Africa (especially in India and Nigeria), with $97 \%$ of millet production in developing countries and according to FAO statistics, the world production of millets was 26.7 million metric tonnes. The crop is favoured due to its productivity and short growing season under dry, high-temperature conditions $[11,12]$. Millet cobs are a great source of lignocellulosic biomass which is renewable, chiefly unexploited and inexpensive. Millets are a group of highly variable small seeded grasses, widely grown around the world as cereal crops or grains for fodder and human food. They do not form a taxonomic group, but rather a functional or agronomic one. Therefore, the present research work undertaken is to determine the suitability of millet cobs for microbial enzymes production.

\section{Materials}

\section{Collection of sample}

Pearl millet (Pennisetum glaucum, Linn) was obtained from a farmland in Gusau, Zamfara State, Nigeria. The millet cobs were kept in a sterile air tight polythene bags and transported to the Microbiology Postgraduate Laboratory, Federal University of Technology, Akure for further analysis.

\section{Preparation of millet cobs}

The millet cobs were sun-dried for 3 weeks and grinded into powder using an electric blender (Binatone Blender). The grinded millet cobs

*Corresponding author: Arogunjo AO, Department of Microbiology, Federal
University of Technology, Akure, Nigeria, E-mail: ayodele.arogunjo@yahoo.com

Received September 14, 2018; Accepted November 09, 2018; Published November 12, 2018

Citation: Arogunjo AO, Arotupin DJ (2018) Millet Cobs: A Source of Microbial Enzymes. J Microb Biochem Technol 10: 124-133. doi: 10.4172/1948-5948.1000405

Copyright: (c) 2018 Arogunjo AO, et al. This is an open-access article distributed under the terms of the Creative Commons Attribution License, which permits unrestricted use, distribution, and reproduction in any medium, provided the original author and source are credited. 
were divided into two portions; A and B. Portion A was left undegraded, while Portion B was degraded for 20 days.

\section{Liquid substrate degradation}

In the submerged substrate degradation, $10.0 \mathrm{~g}$ of the portion $\mathrm{B}$ of the substrate was naturally degraded by soaking in $100.0 \mathrm{~mL}$ of sterile distilled water. Liquid substrate degradation was carried out during which analyses such as: microbial analysis; $\mathrm{pH}$, temperature and titratable acidity determination and enzyme activity were carried out at 4 days interval during millet cobs degradation.

\section{Isolation and identification of microorganisms}

Nutrient agar (NA), nutrient broth (NB), De Man Rogosa and Sharpe Agar (MRSA), De Man Rogosa and Sharpe broth (MRSB), Potato dextrose agar (PDA), Potato dextrose broth (PDB) were prepared according to manufacturer's specification for the isolation of bacteria and fungi. Serial dilution was carried out according to the standard method of Fawole and Oso for the isolation of bacteria $\left(\times 10^{6} \mathrm{cfu} / \mathrm{mL}\right)$ and fungi $\left(\times 10^{4} \mathrm{sfu} / \mathrm{mL}\right)$ [13]. Conventional methods were used in identification of the isolated bacteria and fungi using the standard methods of Fawole and Oso [13]. Molecular identification of isolated bacteria and yeasts were carried out using the standard methods of Tamura, (2011) [14].

\section{Determination of $\mathrm{pH}$}

The electrode of the meter was aseptically inserted into the media after standardization with the appropriate buffer (4 and 7 solutions). The electrode was then left in the media for 3 minutes to stabilize after which the $\mathrm{pH}$ was read at the same time on the meter scale.

\section{Determination of temperature}

Determination of temperature was done using a thermometer. The thermometer was inserted into the substrate 4 day interval to monitor the temperature.

\section{Determination of total titrable acidity (TTA)}

The total titratable acidity of the fermenting extrudates was determined every four day interval as described by AOAC (2012) [15]. Two grams ( $2 \mathrm{~g}$ ) of the sample was weighed into $20 \mathrm{ml}$ of sterile distilled water and filtered. $10 \mathrm{~mL}$ of the filtrate was measured and few drops of phenolphthalein indicator added. This was titrated with 0.1 $\mathrm{M}$ sodium hydroxide $(\mathrm{NaOH})$ solution and the titre values in milliliter were added from the burette.

\section{Enzyme activity}

The enzyme activity of both the undegraded and degraded millet cobs sample was determined using the techniques for cellulase, protease, lipase, pectinase and amylase respectively [16-20].

\section{Microbial screening for enzyme production}

Culture media specific to each enzyme were used for primary screening of enzymes production by following the methods for cellulase, protease, lipase, pectinase and amylase respectively [21-25].

\section{Statistical analyses}

The experimental design was done in triplicate using complete randomization. The data obtained were subjected to analysis of variance (ANOVA) and the means were separated using Duncan's New Multiple Range Test.

\section{Results}

\section{Microbial isolation and identification}

The total bacterial counts $\left(10^{6} \mathrm{cfu} / \mathrm{ml}\right)$, fungal mean counts $\left(10^{4}\right.$ $\mathrm{sfu} / \mathrm{ml}$ ) is shown in Figure 1 and 2. The total bacterial count in the undegraded sample was 7.33 , while that of fungi was 8.67 . The total bacterial counts for the degraded sample ranged from 28.00 to 34.33 , while the range for fungi was 7.00-36.00. The conventional identification of microorganisms isolated from the millet cobs samples is shown in Tables 1-3. The frequency of occurrence of isolated microorganisms is shown in Tables 4 and 5. Molecular identification for Bacillus cereus, Bacillus subtilis, Bacillus licheniformis, Corynebacterium fasciens, Lactobacillus lactis, Lactococcus lactis and Flavobacterium columnare respectively which were later identified using $16 \mathrm{~S}$ rDNA analysis to be Bacillus licheniformis strain ZULMMI012, Bacillus subtilis strain b17a, Macrococcus carouselicus strain H8B16, Bacillus cereus strain pBCO_5, Lactobacillus brevis strain 14.8.28, Lactococcus lactis subsp. lactis strain Mast_19 and Flavobacterium ferrugineum while that of yeasts: Saccharomyces cerevisae, Candida albicans, Candida krusei, Geotrichum albidium and Zygosaccharomyces rouxii respectively which were also identified using $16 \mathrm{~S}$ rDNA analysis to be Candida albicans strain h70b, Saccharomyces cerevisiae strain K289-3A, Rhodotorula mucilaginosa strain G20, Saccharomyces cerevisiae strain BY4742 and Kluyveromyces marxianus strain GX-15 respectively (Figure 3a and 3b).

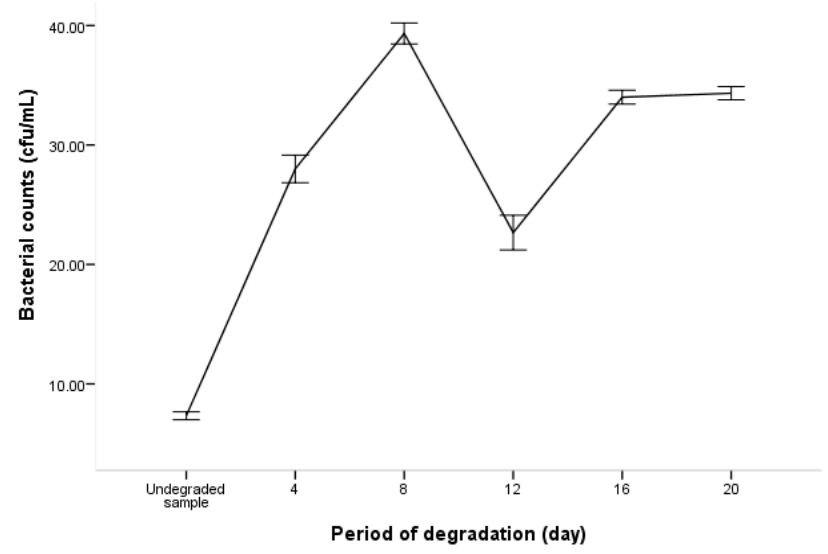

Figure 1: Bacterial counts isolated from millet cobs during degradation.

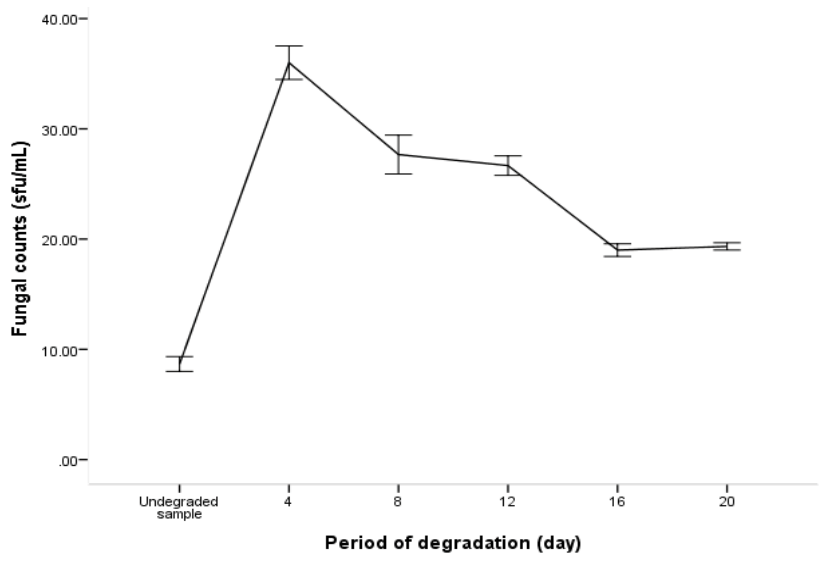

Figure 2: Fungal counts isolated from millet cobs during degradation. 
Citation: Arogunjo AO, Arotupin DJ (2018) Millet Cobs: A Source of Microbial Enzymes. J Microb Biochem Technol 10: 124-133. doi: 10.4172/19485948.1000405

\begin{tabular}{|c|c|c|c|c|c|c|c|}
\hline Laboratory Ref. No & B1 & B2 & B3 & B4 & B5 & B6 & B7 \\
\hline \multicolumn{8}{|l|}{ Colony/Morphology } \\
\hline Colour & Creamy & Creamy & Creamy & Yellow & Creamy & Creamy & Yellow \\
\hline Surface & Opaque & Opaque & Opaque & Opaque & Opaque & Opaque & Translucent \\
\hline Cell Characteristics (microscopy) & Straight Rods & Opaque & Straight Rods & $\begin{array}{l}\text { Single, straight } \\
\text { and short rods }\end{array}$ & $\begin{array}{l}\text { Straight single rod } \\
\text { on short chain }\end{array}$ & Cocci in pairs & Singly cocci \\
\hline \multicolumn{8}{|l|}{ Biochemical Test } \\
\hline Gram's reaction & +ve & $+v e$ & $+\mathrm{ve}$ & $+\mathrm{ve}$ & $+\mathrm{ve}$ & $+v e$ & -ve \\
\hline Catalase Test & + ve & + ve & $+\mathrm{ve}$ & $+\mathrm{ve}$ & -ve & -ve & $-v e$ \\
\hline Motility & $+\mathrm{ve}$ & $+\mathrm{ve}$ & $+\mathrm{ve}$ & $-v e$ & -ve & -ve & -ve \\
\hline Spore & +ve central & +ve central & +ve central & -ve & -ve & -ve & -ve \\
\hline Indole Production & $+\mathrm{ve}$ & $-v e$ & $-v e$ & -ve & -ve & $+v e$ & -ve \\
\hline Starch hydrolysis & +ve & $+\mathrm{ve}$ & + ve & -ve & -ve & -ve & + ve \\
\hline Citrate utilization & $+v e$ & $+v e$ & $+\mathrm{ve}$ & -ve & -ve & -ve & $-v e$ \\
\hline Methyl red & -ve & -ve & -ve & -ve & -ve & -ve & -ve \\
\hline \multicolumn{8}{|l|}{ Sugar Fermentation } \\
\hline Glucose & A- & A- & A- & $A G$ & A- & A- & $A G$ \\
\hline Fructose & A- & A- & A- & -- & $A G$ & A- & A- \\
\hline Maltose & A- & A- & A- & $A G$ & AG & A- & $A G$ \\
\hline Lactose & -- & -- & -- & $A G$ & $A G$ & A- & A- \\
\hline Sucrose & A- & A- & -- & $A G$ & $A G$ & A- & $A G$ \\
\hline Mannitol & A- & A- & -- & -- & -- & -- & A- \\
\hline Probable Bacterium & $\begin{array}{c}\text { Bacillus } \\
\text { licheniformis }\end{array}$ & Bacillus subtilis & Bacillus cereus & $\begin{array}{c}\text { Corynebacterium } \\
\text { fascians }\end{array}$ & $\begin{array}{l}\text { Lactobacillus } \\
\text { lactis }\end{array}$ & Lactococcus lactis & $\begin{array}{c}\text { Flavobacterium } \\
\text { columnare }\end{array}$ \\
\hline
\end{tabular}

Key: +ve $=$ Positive, - ve $=$ Negative, $A G=$ Acid and Gas, A- = Gas, $--=$ Acid and gas absent

Table 1: Morphological and Biochemical Characteristics of Bacterial Isolates from millet cobs.

\begin{tabular}{|c|c|c|c|}
\hline Isolates & Cultural characteristics & Spores/conidia arrangement under the microscope & Identity of isolates \\
\hline $\mathrm{F} 1$ & $\begin{array}{c}\text { Colonies are blue-green with a suede-like surface consisting } \\
\text { of a dense felt of conidiophores }\end{array}$ & $\begin{array}{l}\text { Uniserate and columnar conidial heads with the phalides limited } \\
\text { to the upper two third of the vessicle and curving to the roughly } \\
\text { parallel to each other }\end{array}$ & Aspergillus fumigatus \\
\hline $\mathrm{F} 2$ & $\begin{array}{l}\text { Spores are granular, flat, often with radial grooves, yellow at } \\
\text { first but quickly becomes bright to yellow-green with age }\end{array}$ & $\begin{array}{l}\text { Conidia are globose to subglobose, pale green and } \\
\text { conspicuously echinulate }\end{array}$ & Aspergillus flavus \\
\hline F3 & Spores are white at initial stage and turn grey with maturity & Hyphae is typically branching and form septate & Aspergillus candidus \\
\hline $\mathrm{F} 4$ & Conidia vary in colour from white to grey & $\begin{array}{l}\text { Chains of single-celled conidia produced in basipetal succession } \\
\text { from a specialized conidiogenous cell }\end{array}$ & $\begin{array}{l}\text { Scorpulariopsis } \\
\text { brevicaulis }\end{array}$ \\
\hline F5 & $\begin{array}{c}\text { Conidia grows rapidly, resemble cotton candy and darken } \\
\text { with age }\end{array}$ & $\begin{array}{l}\text { Mycelia are marked by numerous stolons connecting groups of } \\
\text { long sporangiophores }\end{array}$ & Rhizopus stolonifer \\
\hline $\mathrm{F} 6$ & Conidia appears orange & $\begin{array}{l}\text { Microconidia are absent, chlamydospores are intercalary, } \\
\text { exceptionally terminal, spherical to ovoidal }\end{array}$ & Fusarium poae \\
\hline
\end{tabular}

Table 2: Morphological Characteristics of Mould isolates from biodegraded millet cobs.

\begin{tabular}{|c|c|c|c|c|c|c|c|c|c|c|c|c|c|}
\hline \multirow[b]{2}{*}{ 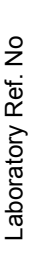 } & \multirow[b]{2}{*}{ Cell shape } & \multicolumn{5}{|c|}{$\begin{array}{c}\text { Morphology } \\
\text { Ascospore }\end{array}$} & \multicolumn{6}{|c|}{$\begin{array}{l}\text { Biochemical Properties } \\
\text { Fermentation/Assimilation }\end{array}$} & \multirow[b]{2}{*}{ Yeast Identity } \\
\hline & & 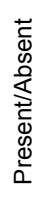 & $\begin{array}{l}\frac{\mathscr{Q}}{\pi} \\
\frac{\frac{2}{\omega}}{\omega}\end{array}$ & $\begin{array}{l}\text { ஸे } \\
\text { के }\end{array}$ & 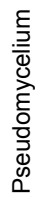 & 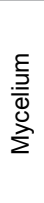 & 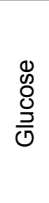 & 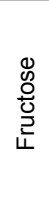 & $\begin{array}{l}0 \\
心 \\
\stackrel{0}{0} \\
心 \\
\omega\end{array}$ & 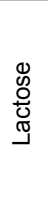 & 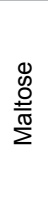 & 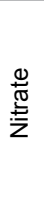 & \\
\hline$Y_{1}$ & Oval & + & Oval & + & + & - & FA & FA & FA & $-A$ & FA & - & Sacharomyces cerevisae \\
\hline$Y_{2}$ & Cylindrical & + & Oval & + & + & - & FA & FA & FA & - & FA & + & Candida albicans \\
\hline$Y_{3}$ & Cylindrical & + & Ovoid & + & + & - & FA & FA & FA & FA & FA & - & Candida krusei \\
\hline $\mathrm{Y}_{4}$ & Cylindrical & + & $\begin{array}{c}\text { Short } \\
\text { Cylindrical }\end{array}$ & + & - & + & FA & FA & $-A$ & $-A$ & FA & + & Geotrichum albidium \\
\hline$Y_{5}$ & Spherical & + & Spherical & + & + & - & FA & FA & FA & $-A$ & FA & - & Zygosaccharomyces rouxii \\
\hline
\end{tabular}

Key: + = Present, - = Absent, FA= Fermentation and Assimilation, $-\mathrm{A}=$ Assimilation only

Table 3: Morphological and Biochemical Characteristics of Yeasts isolated from millet cobs samples. 
Citation: Arogunjo AO, Arotupin DJ (2018) Millet Cobs: A Source of Microbial Enzymes. J Microb Biochem Technol 10: 124-133. doi: 10.4172/19485948.1000405

\begin{tabular}{|c|c|c|c|c|c|c|c|}
\hline \multirow{2}{*}{ 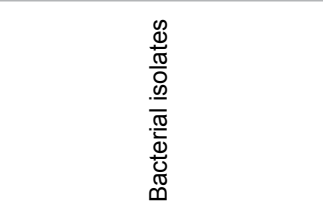 } & \multicolumn{6}{|c|}{ Degradation Period (day) } & \multirow[t]{2}{*}{ Occurrence (\%) } \\
\hline & Undegraded sample & 4 & 8 & 12 & 16 & 20 & \\
\hline Bacillus cereus & + & + & + & - & - & - & 17.79 \\
\hline Bacillus licheniformis & + & + & - & - & - & - & 14.65 \\
\hline Bacillus subtilis & + & + & + & - & - & - & 16.76 \\
\hline Corynebacterium fasciens & - & - & - & + & + & + & 12.77 \\
\hline Flavobacterium ferrugineum & - & + & + & + & + & - & 9.79 \\
\hline Lactobacillus lactis & - & + & + & + & + & + & 16.10 \\
\hline Lactococcus lactis & - & + & + & + & + & + & 12.14 \\
\hline \multirow{2}{*}{ 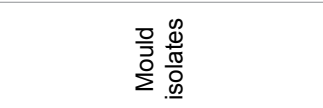 } & \multicolumn{6}{|c|}{ Degradation Period (day) } & Occurrence (\%) \\
\hline & Undegraded sample & 4 & 8 & 12 & 16 & 20 & \\
\hline Aspergillus flavus & + & + & + & - & - & - & 16.41 \\
\hline Aspergillus fumigatus & + & + & - & - & - & - & 16.37 \\
\hline Aspergillus candidus & - & + & + & + & + & - & 20.39 \\
\hline Fusarium poae & - & - & - & + & + & + & 17.03 \\
\hline Rhizopus stolonifer & + & + & + & + & - & - & 17.07 \\
\hline Scopulariopsis brevicaulis & - & - & - & + & + & + & 12.73 \\
\hline \multirow{2}{*}{ 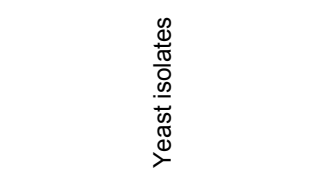 } & \multicolumn{6}{|c|}{ Degradation Period (day) } & Occurrence (\%) \\
\hline & Undegraded sample & 4 & 8 & 12 & 16 & 20 & \\
\hline Candida albicans & + & + & - & - & + & + & 25.76 \\
\hline Candida krusei & + & + & - & - & - & - & 19.18 \\
\hline Geotrichum albidum & - & - & & + & + & + & 20.83 \\
\hline Saccharomyces cerevisiae & - & - & + & + & + & + & 23.90 \\
\hline Zygosaccharomyces rouxii & - & + & - & - & - & - & 10.33 \\
\hline
\end{tabular}

Table 4: Frequency of occurrence of microbial isolates from millet cobs during degradation.

\begin{tabular}{|c|c|c|c|c|}
\hline Conventional identification of isolates & $\begin{array}{l}\text { Sequence with best } \\
\text { match Accession no }\end{array}$ & $\begin{array}{l}\text { Sequence based with } \\
\text { Similar strain }\end{array}$ & Base Pair & Similarity (\%) \\
\hline Bacillus cereus & MH4111110.1 & Bacillus licheniformis strain ZULMMI012 & 1260 & 100 \\
\hline Bacillus subtilis & SPP54602 & Bacillus subtilis strain b17a & 1453 & 95 \\
\hline Bacillus licheniformis & NR_044927.1 & Macrococcus carouselicus strain H8B16 & 1549 & 85 \\
\hline Corynebacterium fasciens & СР009965.1 & Bacillus cereus strain pBCO_5 & 4983 & 100 \\
\hline Lactobacillus lactis & KX301062.1 & Lactobacillus brevis strain 14.8 .28 & 826 & 94 \\
\hline Lactococcus lactis & JQ953678.1 & Lactococcus lactis subsp. lactis strain Mast_19 & 678 & 99 \\
\hline Flavobacteriun columnare & AF335328.1 & Flavobacteriun ferrugineum & 589 & 100 \\
\hline Saccharomyces cerevisiae & KP674770.1 & Candida albicans strain h70b & 510 & 80 \\
\hline Candida albicans & AF058447.1 & Saccharomyces cerevisiae strain K289-3A & 1227 & 97 \\
\hline Candida krusei & KY296083.1 & Rhodotorula mucilaginosa strain G20 & 613 & 97 \\
\hline Geotrichum albidium & NM_001181492.1 & Saccharomyces cerevisiae strain S288C & 1227 & 99 \\
\hline Zygosaccharomyces rouxii & FJ896138.1 & Kluyveromyces marxianus strain GX-15 & 556 & 99 \\
\hline
\end{tabular}

Table 5: Conventional and Molecular Identification of microorganism isolated from Millet Cobs during degradation.

\section{Temperature and $\mathrm{pH}$ variation of the millet cob samples}

Figures 4 and 5 shows the temperature $\left({ }^{\circ} \mathrm{C}\right)$ and $\mathrm{pH}$ variation of both the undegraded and degraded millet cob samples respectively. The highest temperature value was recorded on day 16 with value $28.47 \pm 0.03$ while the lowest temperature was recorded on day 4 with a value of 24.03 . The control sample has the highest $\mathrm{pH}$ with a $\mathrm{pH}$ of 6.50 while the lowest $\mathrm{pH}$ was recorded on day 20 of the biodegradation period with a $\mathrm{pH}$ of 3.81 .

\section{Titratable acidity of the millet cob samples}

Figure 6 show that the undegraded sample (2.31) has the lowest titratable acidity (\%), while the highest was on day 8 (4.21). There were no significant difference $(\mathrm{P}>0.05)$ between the values of days; 12 (4.00), 16 (4.05) and 20 (4.07), however, there was significant difference $(\mathrm{P}<0.05)$ between these days of degradation and day 8 . 


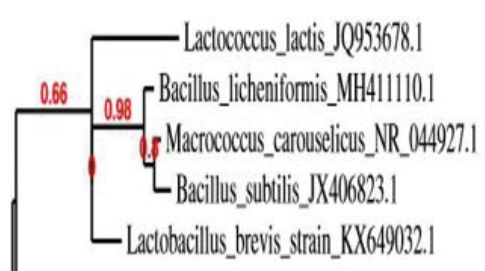

Flavobacterium_ferngineum_AF335328.1

Bacillus_ereus_pBCO_S

\section{3}

Figure 3a: Phylogenic tree of bacteria isolated from millet cobs during degradation.

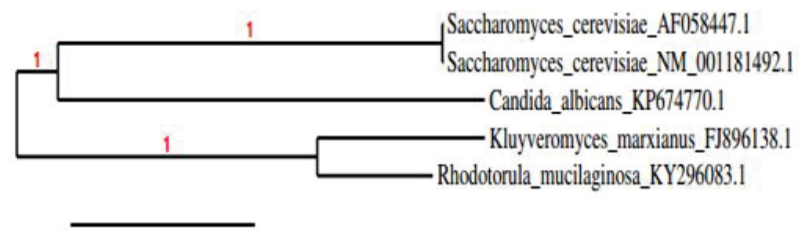

0.2

Figure 3b: Phylogenic tree of yeasts isolated from millet cobs during degradation.

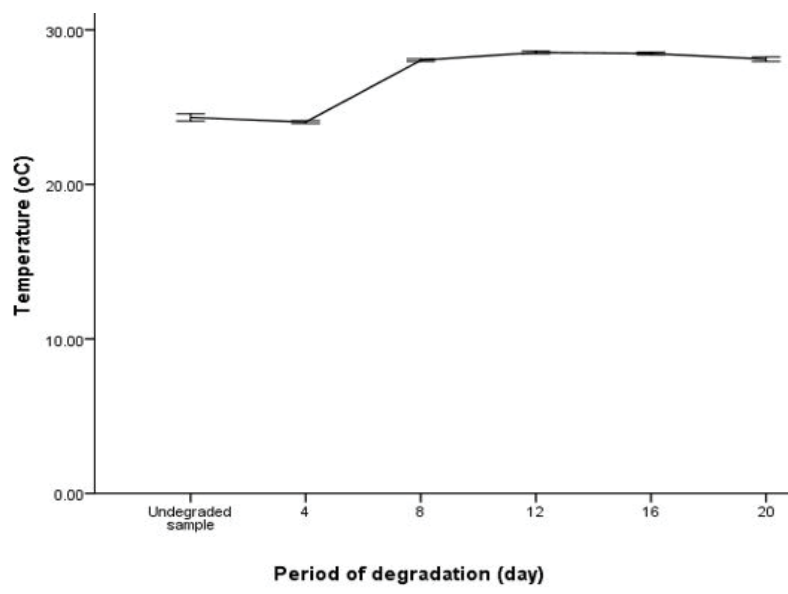

Figure 4: Temperature of the millet cobs during degradation.

\section{Enzyme activity and microbial screening for enzyme production}

The enzyme activities of the millet cob a sample is shown in Figure 7. Lipase has the highest enzyme activity which was recorded on day 20 of the degradation period. The enzyme activities for all the enzymes assayed for were low in the control sample. All the isolated microorganisms exhibited enzymatic activity except $Z$. rouxii (Table 6).

\section{Discussion}

Variation observed in names given using conventional and molecular methods of identification of microorganisms agrees with the findings of Frickmann [26]. They reported differences in names

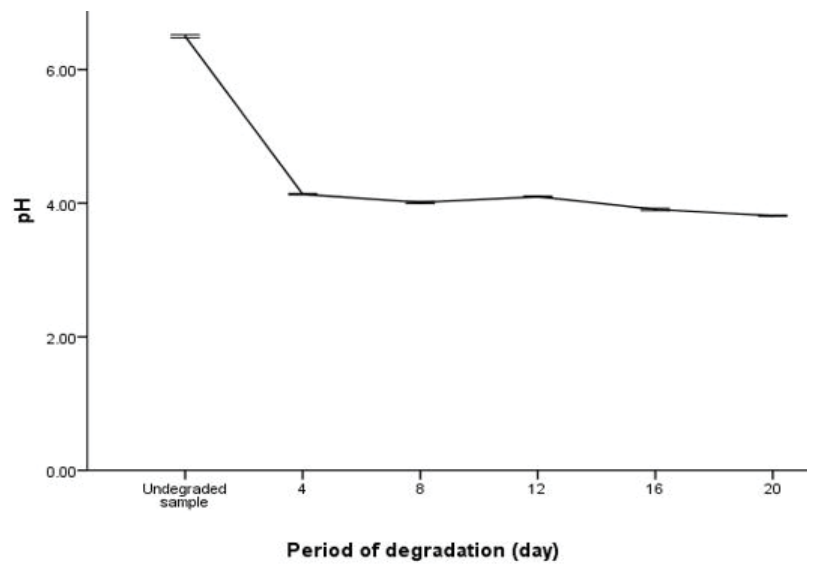

Figure 5: $\mathrm{pH}$ of the Millet cobs during degradation.

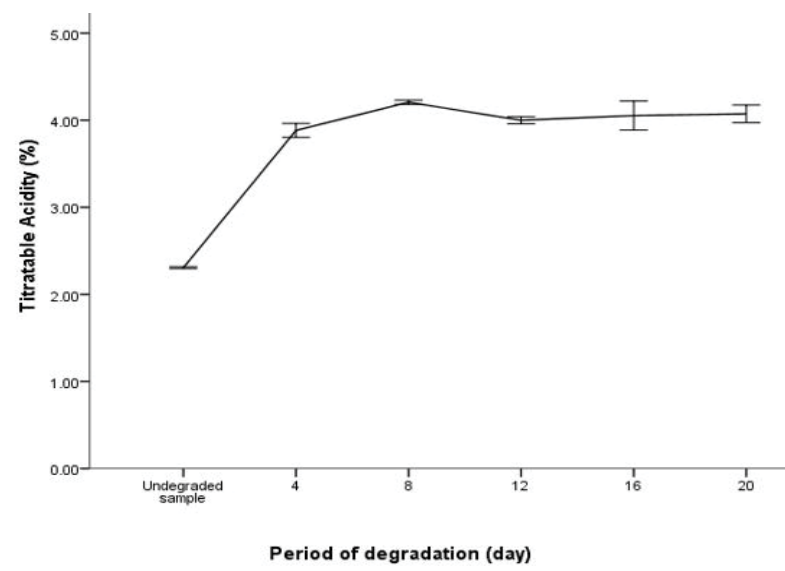

Figure 6: Titratable Acidity of the millet cobs during degradation.

\begin{tabular}{|c|c|c|c|c|c|}
\hline Bacteria & Pectinase & Lipase & Cellulase & Amylase & Protease \\
\hline B. cereus & + & + & + & + & + \\
\hline $\begin{array}{c}\text { B. licheniformis } \\
\text { B. subtilis }\end{array}$ & + & + & + & + & + \\
\hline $\begin{array}{c}\text { Corynebacterium } \\
\text { fascians }\end{array}$ & - & + & + & + & + \\
\hline $\begin{array}{c}\text { Flavobacterium } \\
\text { ferrugunieum }\end{array}$ & - & - & - & - & + \\
\hline Lactobacillus lactis & - & + & + & + & + \\
\hline $\begin{array}{c}\text { Lactococcus lactis } \\
\text { Fungi }\end{array}$ & - & + & + & + & + \\
\hline $\begin{array}{c}\text { Saccharomyces } \\
\text { cerevisae }\end{array}$ & + & + & + & + & + \\
\hline $\begin{array}{c}\text { Geotrichum albidum } \\
\text { Pspergillus fumigatus }\end{array}$ & + & - & - & - & - \\
\hline Aspergillus flavus & + & - & + & + & + \\
\hline Candida krusei & + & - & + & - & + \\
\hline Aspergillus candidus & + & - & + & + & - \\
\hline $\begin{array}{c}\text { Scorpulariopsis } \\
\text { brevicaulis }\end{array}$ & + & - & + & - & - \\
\hline $\begin{array}{c}\text { Rhizopus stonifer } \\
\text { Candida albicans }\end{array}$ & + & - & + & + & + \\
\hline $\begin{array}{c}\text { Fusarium poae } \\
\text { Zygosaccharomyces }\end{array}$ & + & + & - & + & + \\
\hline rouxii & - & - & - & - & - \\
\hline Table & + & + & - & - & + \\
\hline
\end{tabular}

Table 6: Microbial screening for enzyme production. 


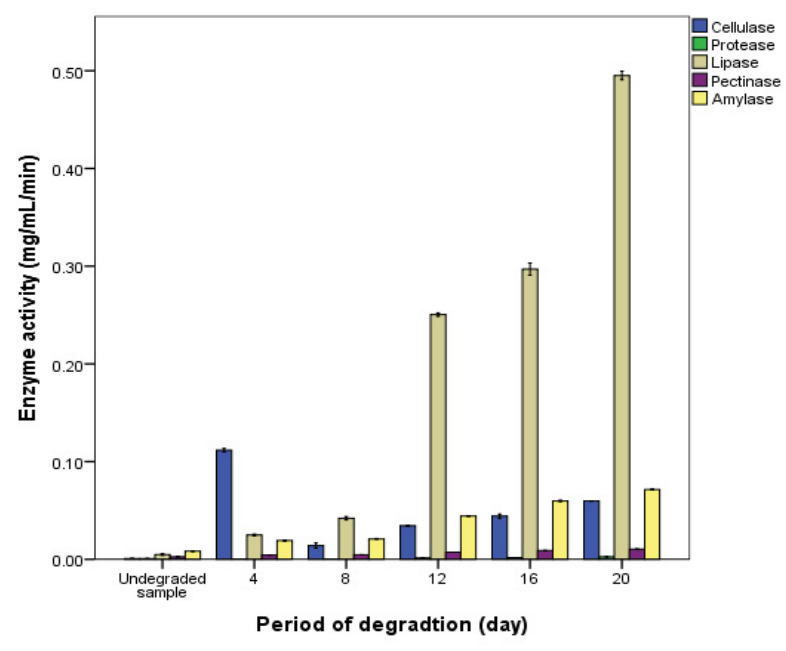

Figure 7: Enzyme activity of millet cobs during degradation.

allotted using conventional and molecular methods of identification. However, the results of this study demonstrated clearly the interest and feasibility to introduce the 16SrRNA gene sequencing method in identification of bacteria and yeasts. Combination of conventional techniques and molecular approach will improve microbiological study and verification, allowing for exclusive and effective identification of microorganisms as against using only conventional method of identification.

The lignocellulosic structure of millet cobs maybe a factor responsible for the low microbial population present particularly in the undegraded sample [27-29]. The presence of bacteria such as B. cereus, $B$. licheniformis and B. subtilis in the undegraded sample agrees with the findings of Kunchala when sorghum and pearl millet from semiarid tropics were characterized for potential probiotic bacteria [30]. The presence moulds such as A. fumigatus, A. flavus and $R$. stolonifer, in the undegraded sample could be a result of them being millet cobs microflora which agrees with the finding of Badau when A. nidulans, $A$. niger, $R$. arrhizus were isolated from unmalted millet grains. Bamigboye also isolated A. flavus, A. niger, Rhizopus oryzae from corn cobs [31,32]. Slightly acidic environment of the millet cobs may be responsible for their adaptation $[33,34]$. The dominant population of A. fumigatus, A. flavus particularly in the undegraded sample maybe due to the presence of nutrients available within the millet cobs for utilization. Nasrin attested to this when combination of molasses and jackfruit were used as a substrate for mutant strain of $A$. niger for citric acid production [34]. The high counts of bacteria, mould and yeast in the millet cobs during degradation may be due to the high concentration of nutrients which agrees with the findings of Arotupin that arrays of microorganisms could increase in population due to the nutrient rich nature of the substrate, thus, supporting the growth and proliferation of microorganisms [35]. Low $\mathrm{pH}$ could be responsible for the increased fungal population [36].

Lactobacillus lactis and Lactococcus lactis are vital organisms for fermentation process which may be responsible for their presence from during degradation. Kalui documented in a review that these bacteria are essential in spontaneously fermenting cereal based food and that these microorganisms produce lactic acid as an important product from the energy yielding fermentation of sugars [37]. Ogbonnaya and Chukwu also attested to this; that majority of lactic acid bacteria isolated from 'Akamu' which is made from maize, a cereal belonged to the Genera: Lactobacillus [38]. Hence, these microorganisms may be implicated as partly responsible for initiating acidification during degradation of millet cobs. Saccharomyces cerevisae and Aspergillus spp may as well be responsible for lactic acid production which concurs with the documentation of Kalui that some yeasts (Saccharomyces) and moulds (Penicillium, Aspergillus and Botrytis) too produce lactic acid [37].

Lactococcus spp also produce ammonia from arginine [37]. All these potential bye-product of $L$. lactis may be responsible for the reduction of other bacterial population which was obtained in the undegraded sample. These conditions created by Lactobacillus lactis and Lactococcus lactis could favour the growth of fungi particularly on day 4 and beyond, thus, Fungi, Lactobacillus and Lactococcus metabolise sugars within the millet cobs which is converted to organic acids.

The growth and population of other microorganisms maybe due to the creation of enabling environment which favour their survival, growth and development of these set of microorganisms. Lactobacilli lactis and Lactococcus latis and mould had the highest population counts towards the end of the degradation period. These conform to the report of Ogbonnaya and Chukwu [38]. Saccharomyces spp, a cabtree positive yeast could utilize the sugars present within the millet cobs for the facilitation of the fermentation process in order to accumulate ethanol in the presence of oxygen particularly during early days of degradation period [39-41]. Candida albicans disappearing on day 8 may be due to the decrease in the available sugars within the millet cobs which might have facilitated their survival, growth, development and proliferation, however, S. cerevisiae becoming dominant on day 12 may be due to the environmental conditions that facilitate their survival, growth, development and proliferation. Candida spp, a cabtree negative yeast catabolizes sugars into carbon dioxide in the presence of oxygen may create an enabling environmental condition which may have facilitated the occurrence of $S$. cerevisae during degradation [42]. However, the reduction in the numbers of $S$. cerevisiae on days 16 and 20 maybe due to their preference for sugars [42]. Increase in the number of Candida spp over Saccharomyces spp on day 16 and 20 maybe due to their utilization of sugars. The reduction in yeast population of days 16 and 20 as compared to day 4 may be due to reduced oxygen [39-41].

The increased population of A. flavus, A. fumigatus and R. stolonifer in day 4 may be as a result of the reduced lignocellulosic component of the millet cobs [27-29]. The increased moisture content of the degraded millet cob as the degradation progressed could be responsible for the reduction in the fungal population [43]. The growth of $A$. Candidus and $F$. poae on days 8 and 12 respectively succeeding $A$. fumigatus maybe a result of factors that may not favour its growth such as low relative humidity [44]. The availability of light may be responsible for the growth of A. fumigatus and A. flavus particularly in the undegraded sample, degraded sample of day 4 which also agrees with the findings of Shehu and Bello while studying the effect of environmental factors on the growth of Aspergillus spp associated with stored millet grains [44]. The growth of A. flavus, though in small population on day 8 shows that $A$. flavus has a higher tolerance level than $A$. fumigatus in darkness. The presence of $A$. candidus from day 8 to day 20 with a relative progressive rise in population could be as a result of increase in the dark condition as the degradation process progresses [44]. The occurrence of $R$. stolonifer on day 8 to day 12 could be as a result of these factors (ability to grow under low relative humidity and in the dark). Scopulariopsis brevicaulis occurred on day 12 and day 20 in which it was the only mould that grew on day 20 of the degraded millet cobs. Hence, S. brevicaulis have the highest survival rate of growing in the dark and in low relative humidity. Also, as the biodegradation 
period increases, relative humidity and light intensity decreases. Thus, these factors could be applicable to bacteria and yeast that grew on the degraded millet cobs.

Millet cobs could serve as a fermentation media for the production of enzymes. Adeleke documented that the production of enzymes by microorganisms in the fermentation media depend on the availability of suitable and utilizable substrate [45]. Rashid concurred that major and minor elements contained within a substrate can be degraded or synthesized by microorganisms using various enzymes [43]. Also, the capacity of microorganisms to produce extracellular enzymes is influenced by environmental conditions such as temperature, $\mathrm{pH}$, aeration, inoculums age and the presence of inducer or repressor substrates $[46,47]$.

The low amount of enzyme activity of all the enzymes assayed for particularly in the undegraded sample may be due to complex structure such as cellulose, hemicellulose and lignin which is important for its utilization and digestibility [33,48-50]. Solid state fermentation for the production of enzymes offers advantages over the conventional method of submerged fermentation [51]. Submerged method of fermentation used may also be attributed to the low enzyme activities [52]. The progressive increase in enzyme activities may be due to the hydrolytic (water) effect on the millet cobs which may increase the surface area and remove hemicellulose. This is in agreement with the findings of Rodolfo that water treatments at elevated temperatures $\left(200-230^{\circ} \mathrm{C}\right)$ and pressures can increase the biomass surface area and remove hemicellulose [53]. The enzyme activity of the millet cobs may have increased if it temperature and pressure were raised.

The presence of cellulase in millet cobs agrees with the separate reports of Sethi and Philip which states that enormous amounts of agricultural, industrial and municipal cellulose wastes contains cellulose [54,55]. The increased cellulase activity on day 4 may be due to the low amount of sugars recorded particularly glucose which may inhibit the production of cellulase while the low cellulase activity on day 12 and the undegraded sample may be due to the increased glucose composition inherent within the millet cobs. It could also be due to the reduced amount of disaccharide cellobiose which could be present within fermented millet cobs which seems to be a more potent inhibitor of cellulase [56]. Payne et al. documented that a large number of compounds such as glucose, mannose, galactose, xylose, ethanol and various ions can act as possible inhibitor for cellulose [57]. The undegraded sample offered reduced accessibility to cellulose and hemicellulose and degradability for enzymatic or chemical action which agrees with the findings of Barakat and Gao $[56,58]$.

The presence of Bacillus spp may contribute to the production of cellulase in the degrading millet cobs which were shown by the zone of hydrolysis in their screening for cellulase production. Separate findings of Akhtar and Saowapar agrees with this finding when different species of Bacillus produced cellulose [21,29]. Shilpa and Pethe also isolated different cellulolytic bacteria from the soil in which $B$. thurigenesis showed the highest zone of hydrolysis when these bacteria were optimized at different condition [59]. The $\mathrm{pH}$ may also be a limiting factor to the low production of cellulase within the millet cobs during degradation. Shilpa and Pethe documented that Bacillus subsp subtilis A-54 has optimum $\mathrm{pH}$ of 6.5 and stable in $\mathrm{pH}$ range of 6.5-8.0 [59]. Sadhu and Maiti stated that the optimum temperature for Bacillus sp to produce cellulase in high quantity is between $37^{\circ} \mathrm{C}$ to $55^{\circ} \mathrm{C}$ [60]. Aspergillus fumigatus, A. flavus and A. candidus that were positively screened for cellulase production agrees with the separate findings of Jabasingh, Liu, Amorea and Faracoa that A. acculeatus, A. fumigatus,
A. niger were confirmed to be producers of cellulose [61-63]. Yeasts such as $S$. cerevisae and Candida spp have shown capacity to produce cellulase [64].

Lactococcus lactis and Lactobacillus lactis being protease producers agrees with the finding of Hnin that proteolytic activity is an important characteristic of lactic acid bacteria [65]. Bacillus spp production of protease agrees with the findings of Hamza and Woldesenbet when Bacillus sp. Cab44 was observed to hydrolyse casein [65]. Alemu reported that $B$. licheniformis, B. firmus, B. alcalo B. subtilis and $B$. thuringiensis were producers of protease [66]. All the Aspergillus spp being producer of protease agrees with the report of Alemu that $A$. flavus, A. miller, A. niger and P. griseofulvinare were protease producers [66]. Oyeleke documented that $A$. flavus and A. fumigatus were able to produce extracellular protease [67]. Oyeleke observed that when $A$. flavus and A. fumigatus were subjected to the same temperature of $30^{\circ} \mathrm{C}$, A. flavus was able to produce the highest amount of protease. Rhizopus stolonifer, a fungus also screened positive for protease production agrees with the findings of Devi that moulds of genera Aspergillus, Penicillium and Rhizopus are useful for producing proteases, as several species of these genera are generally regarded as safe [68]. Sharp decrease of protease activity from day 12 to day 16 could be due to the ability of microorganisms to utilize sugar faster than protein. Dash et al. reported that Bacillus sp isolated from soil has maximum protease activity at optimum $\mathrm{pH}$ of 9.0. Bacillus amyloliquefaciens, $B$. subtilis, B. licheniformis and $B$. stearothermophilus were reported to produce protease at $37-60^{\circ} \mathrm{C}$ [68]. Optimum temperature for protease production in Bacillus spp has also been reported at $35-80^{\circ} \mathrm{C}$ [69]. Oyeleke documented that the optimum temperature for proteases production for both A. flavus and A. fumigatus was $30^{\circ} \mathrm{C}$ [67]. Oyeleke documented that optimum $\mathrm{pH}$ for A. flavus is 8.0 while A. fumigatus is 5.0. Devi reported optimum $\mathrm{pH}$ of 8.5 for protease production by A. niger, although, this is at variance with Siala et al. that reported optimum temperature of 60 and $90^{\circ} \mathrm{C}$ and optimum $\mathrm{pH}$ of 3.0 and 9.0 for proteases produced by $A$. niger [70,71]. These factors could be responsible for protease showing low activity.

The various Bacillus spp isolated from the millet cob samples are the best producer of lipase based on the zone of hydrolysis. Bacillus licheniformis strains, B. licheniformis - $\mathrm{Ht} 7$ have been identified to be good producer of lipase [72]. Lactic acid bacteria isolated from the millet cobs during degradation exhibiting lipase activity concurred with the documentation that Lactobacillus $\mathrm{sp}$ is a producer of lipase which is used for meat degradation [73]. Candida albicans and A. flavus, screened positive for lipase production agrees with the documentation of Singh that C. Antarctica, C. lipolytica and A. flavus are producers of lipase [74]. Singh et al. also observed that different lipase producing bacteria and fungi produced maximum lipase between $\mathrm{pH} 5.0$ and 10.0 [74]. Padmapriya et al. observed lipase production increased with increase in temperature from 30 to $40^{\circ} \mathrm{C}$ and maximum production of lipase was obtained at $40^{\circ} \mathrm{C}$ and production declined at $50^{\circ} \mathrm{C}$ with different Bacillus spp and Lactobacillus spp [73]. Microorganisms were not subjected to these conditions, yet, lipase activity was highest among the enzymes evaluated.

Fungi are better producers of pectinase when compared to bacteria based on the findings of this research. Only Bacillus spp isolated where indicated to be a producer of pectinase. This agrees with different documentations of Bayoumi et al., Geetha et al., Mukesh et al., Darah et al., Raju and Divakar, Roosdiana et al., Kavuthodi et al. and Reddy et al. that most of the Bacterial isolates (mostly Bacillus spp and Pseudomonas spp) such as; Pseudomonas fluorescence and B. subtilis, Bacillus sp. 
MFW7, B. cereus, B. licheniformis, B. cereus, Bacillus sp. MBRL576, B. firmus I-4071, Enterobacter aerogenes NBO2, Pseudoalteromonas haloplanktis strain ANT/505, Paenibacillus xylanolyticus, B. firmus, B. firmus (P1), B. coagulans (P13), B. endophyticus (P57) and B. vietnamensis (P58), B. subtilis BKDS1, Enterobacter sp. PSTB-1 and Staphylococcus aureus were reported as good pectinase producers [7582]. Bacillus subtilis being a producer of pectinase agrees with the report of Mariam and Aruna that B. subtilis strain arium 1115 produced the highest quantity of extracellular pectinase out of the arrays of Bacillus spp assayed for [83]. Many strains of Bacillus have been previously reported to produce extracellular pectinases, such as B. subtilis Strain NVFO 19 (El-sayed, 2015), marine B. subtilis, B. subtilis BKDS1, B. sphaericus MTCC 7542, B. sp. MBRL576, B. licheniformis KIBGEIB21, B. cereus, B. subtilis, B. stearothermophilus, B. firmus and B. cereus [8089]. $\mathrm{pH}$ could also be a factor for low pectinase production in which acidic $\mathrm{pH}$ values were observed during the degradation of the millet cobs. According to the finding of Mariam and Aruna, B. subtilis strain arium 1115 produced the highest amount of pectinase at $\mathrm{pH} 9(21.44$ $\mathrm{U} / \mathrm{mL})$ as against $\mathrm{pH} 3(0.61 \mathrm{U} / \mathrm{mL})$ [83]. This could be a limiting factor for pectinase production especially for Bacillus spp isolated from the millet cobs sample but some species like Bacillus sp. MBRL576 and B. circulans have optimum $\mathrm{pH}$ at 4.0 and 7.0 respectively $[81,88]$. Temperature is another factor to consider for pectinase production. Bacillus species have demonstrated slightly higher temperature for pectinase production such as marine $B$. subtilis and B. circulans at $40^{\circ} \mathrm{C}$ [86,81]. However, findings show B. cereus, B. firmus I-10104, B. cereus and $B$. endophyticus and $B$. coagulans exhibited maximum pectinase production at $37^{\circ} \mathrm{C}[90-92]$. Simran and Vijay attested that Bacillus subtilis isolated from different agro-industrial wastes were able to produce pectinase at a temperature of $35^{\circ} \mathrm{C}$ and at $\mathrm{pH} 7.0$ [93]. The temperature range of millet cobs during degradation fall short of these values.

All the fungal isolates that were screened positive for the production of pectinase may be responsible for the progressive increase in pectinase activity. Arotupin et al. revealed that $A$. repens is capable of hydrolyzing pectin. The hydrolysis of pectin by A. flavus, A. versicolor and A. niger have been reported $[94,95]$. Arotupin et al. revealed that temperature at $30^{\circ} \mathrm{C}$ is optimum for the production of pectinase by A. repens [94].

Amylase activity in the millet cobs during degradation may be as a result of the presence of high concentration of hemicellulose carbohydrate particular starch within the millet cobs. This agrees with the findings of Singh et al. when amylase and xylanase content of rice bran, corn cob, wheat bran, wheat straw, and sugarcane bagasse were described in relation with the composition of starch and hemicellulose [95]. The progressive increase in amylase activity in the fermented millet cobs from day 4 to day 20 could be due to the availability of microorganisms such as $B$. cereus, $B$. licheniformis, $B$. subtilis, Lactobacillus lactis, Lactococcus lactis, A. flavus, A. fumigatus, A. candidus, Fusarium poae, Scorpulariopsis brevicaulis, C. albicans, and $S$. cerevisae in the degrading substrate. This consortium of microorganisms may contribute to the high amylase production. Akpomie et al. reported that Bacillus spp and Lactobacillus sp have ability to produce amylase [25]. Prakash and Jaiswal reported that $B$. subtilis, B. stearothermophilus, B. lecheniformis and B. amyloliquefaciens are known to be the good producers of thermostable $\alpha$ - amylase [96]. Sundarapandiyan and Jayalakshmi isolated, characterized and screened Bacillus subtilis SJ33 from marine environment for amylase production [97]. It is also to be known Prakash and Jaiswal stated in one of their findings that thermophilic bacterium B. stearothermophilus offers an alternative for commercial production of thermostable $\alpha$-amylases [96]. Hence, Bacillus spp are known to be commercial producer of amylase. Filamentous fungi, such as $A$. oryzae and $A$. niger produce considerable quantities of enzymes that are used extensively in the industry [98]. Progressive increase in temperature could also be another factor that led to the progressive increase in amylase production which may be a satisfactory condition that made the microorganisms to produce more amylase. Akpomie et al. attested to this fact that gradual increase in amylase activity was observed from 26 to $45^{\circ} \mathrm{C}$ and beyond this range it declined [25]. Thus, temperature contributes to the factor responsible for the secretion of amylase. Cavalheiro et al. documented that high enzymatic activity for amylase production by Gongronella butleri was between $\mathrm{pH}$ ranges of 4.0-5.5 [99]. Nwagu and Okolo reported that amylase produced by $A$. fumigatus maintained $94 \%$ of its activity at pH 4.5-6.5 for 24 hours [99]. de-Souza and Magalhães reported that $A$. niger has important hydrolytic capacities in amylase production and its tolerance of acidity $(\mathrm{pH}<3)$ could be a factor in the production of amylase by different Aspergillus spp isolated [100]. Sujeeta et al. reported that amylase activity of yeast isolates may increase at a temperature of $30^{\circ} \mathrm{C}$. The temperatures obtained during the degradation of the millet cobs were below this [101].

\section{Conclusion}

A Millet cob shows amylase, cellulytic, pectinolytic, lipolytic, proteolytic and amylytic activities when degraded by inherent microorganisms. Further studies on the millet cobs particularly on improving the microbial enzymatic activities in order to explore their potent value in commercial application should be carried out.

\section{References}

1. Bajpai P, Bajpai PK (1989) High-Temperature Alkaline a-Amylase From Bacillus iicheniformis TCRDC-B13. Biotech Bioeng 33: 72-78.

2. Hill J, Nelson E, Tilman D, Polasky S, Tiffany D (2006) Environmental, Economic, and Energetic Costs and Benefits of Biodiesel and Ethanol Biofuels. Pro Nat Acad Sci USA 314: 1598-1600.

3. Sangrila S, Tushar KM (2013) Cellulase Production by Bacteria: A Review. British Microbiol Res J 3: 235-258.

4. Hasan F, Shan AA, Hameed A (2006) Industrial Applications of Microbial Lipases. Enzyme Microb Technol 39: 235-251.

5. Rachana C (2017) Isolation and Screening of Lipase Producing Bacteria from Oil Mill Effluent. Indian J Sci Res 13: 192-194.

6. Kiro M (2010) The Effects of Different Carbon Sources on Biosynthesis of Pectinolytic Enzymes by Aspergillus Niger. ATI - Appl Technol Innov 3: 23-29.

7. Kumar D, Savitri N, Thakur RV, Bhalla TC (2008) Microbial Proteases and Application as Laundry Detergent Additive. Microbiol 3: 661-672.

8. Mala BR, Aparna MT, Mohinis G, Vasanti VD (1998) Molecular and Biotechnological Aspect of Microbial Proteases. Microbiol Molec Bio Rev 62 597-635.

9. Hamid M, Ikram-ul-haq (2008) Production of Alkaline Protease by Bacillus subtilis and its Application as a Depilating Agent in Leather Processing. Pak J Bot 40: 1673-1679.

10. Ras MB, Aparna M, Tanksale M, Hatage S, Deshande VV (1998) Molecula and Biotechnological Aspects of Microbial Protease. Microbiol Mol Bio Rev 62: 597-635.

11. FAO (2009) FAOSTAT. Food and Agriculture Organisation of the United Nations.

12. Dayakar RB, Bhaskarachary K, Arlene CGD, Sudha DG, Vilas AT (2017) Nutritional and Health Benefits of Millets. ICAR_Indian Institute of Millets Research (IIMR) Pp: 112.

13. Fawole MO, Oso BA (2007) Laboratory manual of Microbiology. 5th Edition, Spectrum Books Limited, Ibadan, Pp: 22-23.

14. Tamura K, Peterson D, Peterson N, Stecher G, Nei M, et al. (2011) 
MEGA5: Molecular Evolutionary Genetics Analysis Using Maximum Likelihood, Evolutionary Distance, and Maximum Parsimony Methods. Mol Bio Evol 28: 2731-2739.

15. AOAC (2012) Official Methods of Analysis, Association of Official Analytical Chemist. 19th edition, Washington DC, USA.

16. Miller GL (1959) Use of Dinitrosalycilic Acid (DNSA) Reagent for the Determination of Reducing Sugar. Analyt Chem 31: 426-428.

17. Ladd JN, Butler JHA (1972) Short-term Assay on Soil Proteolytic Enzyme Activity Using Proteins and Dipeptide Substrate. Soil Biol Biochem 4: 19-39.

18. Maia MD, Morais CD, Morais AD, Melo HM, Filho JL (1999) Production of Extracellular Lipase by the Phytopathogenic Fungus Fusarium solani FS1. Rev Microbiol 30: 304-309.

19. Mandels M, Andreotti R, Roche C (1976) Measurements of saccharifying cellulase. Biotech Bioeng Symp 6: 21-33.

20. Bernfeld $P$ (1951) Amylase $a$ and $b$ in Methods in Enzymes. Academic Press, New York, 144-147.

21. Saowapar K, Yupa P, Taweesak T, Somboon T (2014) Screening and Identification of Cellulase Producing Bacteria Isolated from Oil Palm Meal. J Appl Pharm Sci 4: 90-96.

22. Hnin E, Zaw KO, Kyaw NA (2015) Screening on Proteolytic Activity of Lactic Acid Bacteria from Various Yogurts and Fermented Milk. Intl J Adv Sci Eng Technol 15: 34-37.

23. Toshi W, Sudhir KJ (2017) Isolation, Screening and Identification of Lipase Producing Fungi from Oil Contaminated Soil of Shani Mandir Ujjain International J Curr Microbiol Appl Sci 6: 1872-1878.

24. Hankin L, Zucker M, Sands DC (1971) Improved Solid Medium for the Detection and Enumeration of Pectolytic Bacteria. Appl Microbiol 22: 205-209.

25. Akpomie OO, Akponah E, Okorawhe P (2012) Amylase Production Potentials of Bacterial Isolates obtained from Cassava Root Peels. Agric Sci Res J 2: 95-99.

26. Frickmann H, Loderstaedt U, Racz $P$, Tenner-Racz K, Eggert $P$, et al. (2015) Detection of Tropical Fungi in Formalin-Fixed, Paraffin-Embedded Tissue: Still an Indication for Microscopy in Times of Sequence-Based Diagnosis? BioMed Res Intl 2015: 938721-938799.

27. Hendricks ATWM, Zeeman G (2009) Pretreatments to Enhance the Digestibility of Lignocellulosic Biomass. Biores Technol 100: 10-18.

28. Agbor VB, Cicek N, Sparling R (2011) Biomass Pretreatment: Fundamentals toward Application. Biotech Adv 29: 675-685

29. Akhtar N, Sharma A, Deka D (2012) Characterization of Cellulase Produced of Bacillus sp. for Effective Degradation of Leaf Litter Biomass. Environ Prog Sus Energy 32: 1195-1201.

30. Kunchala R, Banerjee R, Mazumdar SD, Durgalla P, Srinivas V, et al. (2016) Characterization of Potential Probiotic Bacteria Isolated from Sorghum and Pearl millet of the Semi-Arid Tropics. African J Biotechnol 15: 613-621.

31. Badau MH (2006) Microorganisms Associated with Pearl Millet Cultivars at Various Malting Stages. Inter J Food Safety 8: 66-72.

32. Bamigboye OO (2013) Screening of Some Fungi Associated with Maize Cob Degradation for Cellulase Activity. Green J Bio Sci 3: 208-212.

33. Murali N, Srinivas K, Ahring BK (2017) Biochemical Production and Separation of Carboxylic Acids for Biorefinery Applications. MDPI. Fermentation 3: 1-22.

34. Nasrin S, Ansary M U, Alam KM (2017) Optimization of Citric Acid Production by Substrate Selection using Gamma Ray Induced Mutant Strain of Aspergillus niger. Global J Med Res: Microbiol Pathol 17: 22-30.

35. Arotupin DJ, Awojobi KO, Owolabi TR, Eze C (2016) Microorganisms Associated with African Star Apple (Chrysophylum albidum) and their Hydrolases. African J Microbiology Res 10: 225-230.

36. Bello BK, Akinyele BJ (2007) Effect of Fermentation on the Microbiology and Mineral Composition of an Edible Mushroom Termitomyces robustus (Fries). Intl J Bio Chem 4: 237-243.

37. Kalui CK, Mathara JM, Kutima PM (2010) Probiotic Potential of Spontaneously Fermented Cereal Based Foods-A Review. African J Biotechnol 9: 2490-2498.

38. Ogbonnaya N, Chukwu BC (2012) Studies on Akamu, a Traditional Fermented Maize Food. Rev Chil Nutri 39: 180-185.
39. Merico A, Sulo P, Piskur J, Compagno C (2007) Fermentative Lifestyle in Yeasts Belonging to the Saccharomyces Complex. FEBS Journal 274: 976-7b89.

40. Walker GM, Stewart GG (2016) Saccharomyces cerevisiae in the Production of Fermented Beverages. Beverages 2: 30-41.

41. Alonso-del-Real J, Lairón-Peris M, Barrio E, Querol A (2017) Effect of Temperature on the Prevalence of Saccharomyces Non cerevisiae Species against a $S$. cerevisiae Wine Strain in Wine Fermentation: Competition Physiological Fitness, and Influence in Final Wine Composition. Front Micro 8: 150-198.

42. Azhar SHM, Siti RM, Jambo A, Marbawi H, Gansau JA (2017) Yeasts in Sustainable Bioethanol Production: A review. Biochem Biophy Rep 10: 52-61.

43. Rashid MI, Mujawar LH, Shahzad T, Almeelbi T, Ismail IMI, et al. (2016) Bacteria and Fungi can Contribute to Nutrients Bioavailability and Aggregate Formation in Degraded Soils. Microbiol Res 183: 26-41.

44. Shehu K, Bello MT (2012) Effect of Environmental Factors on the Growth of Aspergillus species Associated with Stored Millet Grains in Sokoto. Nigerian J Bas Appl Sci 19: 218-223.

45. Adeleke BS, Olaniyi OO, Akinyele BJ (2017) Isolation and Screening of Bacteria Associated with Fermented Cassava Peels for Linamarase Production. Intl J Appl Biotechnol Res 5: 20-26.

46. Nigam P (2013) Microbial Enzymes with Special Characteristics for Biotechnological Applications. Biomolecules 3: 597-611.

47. Hasan S, Ahmad A, Purwar A, Khan N, Kundan R, et al. (2013) Production of Extracellular Enzymes in the Entomopathogenic Fungus Verticillium lecanii. Bioinformation 9: 238-242.

48. Tejado A, Pena C, Labidi J, Echeverria JM, Mondragon I (2007) PhysicoChemical Characterization of Lignins from Different Sources for Use in PhenolFormaldehyde Resin Synthesis. Biores Technol 98: 1655-1663.

49. Cao S, Pu Y, Studer M, Wyman C, Ragauskas AJ (2012) Chemical Transformations of Populus trichocarpa During Dilute Acid Pretreatment. Royal Soc Chem Adv 2: 10925-10936.

50. Li M, Pu Y, Ragauskas AJ (2016) Current Understanding of the Correlation of Lignin Structure with Biomass Recalcitrance. Front Chem 4: 1-8.

51. Cruz R, Fonseca JC, Fernandes MJS, Lima DMM, Duda GP, et al. (2013) Diversity of Filamentous Fungi of Area from Brazilian Caatinga and High-Leve Tannase Production Using Mango (Mangifera indica L.) and Surinam Cherry (Eugenia uniflora L.) Leaves under SSF. Adv Microbiol 3: 52-60.

52. Colla LM, Ficanha AMM, Rizzardi J, Bertolin TE, Reinehr CR, et al. (2015) Production and Characterization of Lipases by Two New Isolates of Aspergillus through Solid-State and Submerged Fermentation. BioMed Res Intl 2015: 725-734.

53. Rodolfo QR (2014) Hydrolysis of Lignocellulosic Biomass. In Luis Augusto Barbosa Cortez. SãoPaulo: Editora Edgard Blücher. Sugarcane bioethanol R\&D for Productivity and Sustainability. Pp: 717-732.

54. Sethi S, Datta A, Gupta BL, Gupta S (2013) Optimization of Cellulase Production from Bacteria Isolated from Soil. ISRN Biotech 2013: 985685-985709.

55. Philip J, Tanuja T, Bedi S (2016) Occurrence of Cellulose Degraders in Fruit and Vegetable Decaying Wastes. Bioremed Biodegrad 7: 6-10.

56. Gao DM, Kobayashi T, Adachi S (2015) Production of Keto-Disaccharides from Aldo-Disaccharides in Subcritical Aqueous Ethanol. Food Nutri Sci 80: 9981005.

57. Payne CM, Knott BC, Mayes HB, Hansson M, Himmel ME, et al. (2015) Fungal Cellulases. Chem Rev 115: 1308-1448.

58. Barakat A, Mayer C, Solhy A, Arancon RAD, De-Vries H, et al. (2014) Mechanical Pretreatments of Lignocellulosic Biomass: Towards Facile and Environmentally Sound Technologies for Biofuels Production. RSC Adv 4: 48109-48127.

59. Shilpa L, Pethe AS (2017) Isolation and Screening of Cellulolytic Bacteria from Soil and Optimization of Cellulase Production. Intl J Life Sci 5: 277-282.

60. Sadhu S, Maiti TK (2013) Cellulase Production by Bacteria: A Review. Brit Microbiol Res J 3: 235-258

61. Jabasingh SA (2011) Utilization of Pretreated Coir Pith for the Optimized Bioproduction of Cellulase by Aspergillus nidulans. Intl J Biodeterior Biodegrad 65: $1150-1160$. 
62. Liu D, Zhang R, Yang XH, Xu D, Tang Z, et al. (2011) Thermostable Cellulase Production of Aspergillus fumigatus Z5 Under Solid-State Fermentation and Its Application in Degradation of agricultural wastes. Intl Biodeterior Biodegrad 65: 717-725.

63. Amorea A, Faracoa V (2012) Potential of Fungi as Category I Consolidated BioProcessing Organisms for Cellulosic Ethanol Production. Renew Sus Energy Rev 16: 3286-3301.

64. Maki M, Leung KT, Qin W (2009) The Prospects of Cellulase-Producing Bacteria for the Bioconversion of Lignocellulosic Biomass. Intl J Bio Sci 5: 500-516.

65. Hamza TA, Woldesenbet F (2017) Optimization of Culture Growth Parameters for Production of Protease from Bacteria, Isolated from Soil. Biosci Bioeng 3: 1-10.

66. Alemu $F$ (2015) Isolation and Screening of Protease Enzyme Producing Bacteria from Cheese at Dilla University, Ethiopia. Intl J Nut Food Sci 4 234-239.

67. Oyeleke SB, Egwim EC, Auta SH (2010) Screening of Aspergillus flavus and Aspergillus fumigatus strains for extracellular protease enzyme production. $\mathrm{J}$ Microbiol Antimicrob 2: 83-87.

68. Palsaniya P, Mishra R, Beejawat N, Sethi S, Lal GBL (2012) Optimization of Alkaline Protease Production from Bacteria Isolated from Soil. Microbio Biotechn Res 23: 858-865.

69. Rodrigues RC, Ortiz C, Berenguer-Murcia A, Torres R, Fernandez-Lafuente R (2013) Modifying Enzyme Activity and Selectivity by Immobilization. Chem Soc Rev 42: 6290-307.

70. Devi MK, Banu AR, Gnanaprabhal GR, Pradeep BV, Palaniswamy M (2008) Purification, Characterization of Alkaline Protease Enzyme from Native Isolate Aspergillus niger and Its Compatibility with Commercial Detergents. Indian J Sci Technol 1: 7-24.

71. Siala R, Sellami-kamoun A, Hajii M, Abid I, Gharsallah N, et al. (2009) Extracellular Acid Protease from Aspergillus niger 11: Purification and Characterization. African J Biotech 8: 4582-4589.

72. Ugras S (2017) Characterization of a Thermophilic Lipase from Bacillus licheniformis Ht7 Isolated from Hayran Thermal Springs in Giresun. Rom Biotechnol Lett 22: 12297-12304.

73. Padmapriya B, Rajeswari T, Noushida E, Sethupalan DG, Venil CK (2011) Production of Lipase Enzyme from Lactobacillus spp. and Its Application in the Degradation of Meat. World Appl Sci J 12: 1798-1802.

74. Singh R, Kumar M, Mittal A, Mehta PK (2016) Microbial Enzymes: Industrial Progress in 21st Century. 3 Biotech 6: 174-188.

75. Bayoumi R, Hesham A, Yassin M, Mahmoud A, Swelim E (2008) Production of Bacterial Pectinases from Agro-Industrial Wastes Under Solid State Fermentation Conditions. J Appl Sci 4: 1708-1721.

76. Geetha M, Saranraj P, Mahalakshmi S, Reetha D (2012) Screening of Pectinase Producing Bacteria and Fungi for Its Pectinolytic Activity Using Fruit Wastes. Intl J Biochem Biotechnol Sci 1: 30-42.

77. Mukesh KDJ, Saranya GM, Suresh K, Andal Priyadharshini D, Rajakumar $\mathrm{R}$ (2012) Production and Optimization of Pectinase from Bacillus sp. MFW7 Using Cassava Waste. Asian J Plant Sci Res 2: 369-375.

78. Darah I, Nisha M, Lim SH (2013) Polygalacturonase Production by Calcium Alginate Immobilized Enterobacter aerogenes NBO2 Cells. Appl Biochem Biotech 175: 2629-36.

79. Raju VNE, Divakar G (2013a) Production of Pectinase by Using Bacillus circulans Isolated from Dump Yards of Vegetable Wastes. Intl J Pharm Sci Res 4: 2615-2622.

80. Roosdiana A, Prasetyawan S, Mahdi C (2013) Production and Characterization of Bacillus firmus Pectinase. J Pure Appl Chem Res 2: 35-41.

81. Kavuthodi B, Thomas SK, Sebastian D, Martinez-Sobrido L, Mohamed EA
(2015) Co-Production of Pectinase and Biosurfactant by the Newly Isolated Strain Bacillus subtilis BKDS1. British Microbiol Res J 10: 112-131.

82. Reddy MPC, Saritha KV (2016) Effects of the Culture Media Optimization on Pectinase Production by Enterobacter sp. PSTB-1. 3 Biotech 6: 1-11.

83. Mariam K, Aruna K (2017) Optimization and Partial Characterization of Pectinase Produced by Bacillus subtilis strain arium 1115 Isolated from Spoilt Apple. Intl J Rec Sci Res 8: 19633-19644.

84. El-sayed MH (2015) Thermoalkali-Stable Pectinase from Bacillus subtilis Strain NVFO 19 Isolated from Agricultural Waste Dump Soil. Curr Res Microbio Biotechnol 3: 805-815.

85. Joshi M, Nerurkar M, Adivarekar R (2013) Use of Citrus Limetta Peels for Pectinase Production by Marine Bacillus Subtilis. Innov Rom Food Biotechnol 12: $75-83$.

86. Jayani RS, Shukla SK, Gupta R (2010) Screening of Bacterial Strains for Polygalacturonase Activity: Its Production by Bacillus sphaericus (MTCC 7542). Enzyme Res 22: 1-5.

87. Bhardwaj V, Garg N (2014) Production, Purification of Pectinase from Bacillus sp. MBRL576 Isolate and its Application in Extraction of Juice. Intl J Sci Res 3: $648-652$.

88. Rehman HU, Nawaz MA, Aman A, Baloch AH, Qader SAU (2015) Immobilization of pectinase from Bacillus licheniformis KIBGE-IB21 on chitosan beads for continuous degradation of pectin polymers. Biocat Agric Biotech 3: 282-287.

89. Torimiro N, Okonji ER (2013) A Comparative Study of Pectinolytic Enzyme Production by Bacillus species. African J Biotech 12: 6498-6503.

90. Namasivayam E, John Ravindar D, Mariappan K, jiji A, Kumar M, et al. (2011) Production of Extracellular Pectinase by Bacillus Cereus Isolated from Market Solid Waste. J Bioanal Biomed 3: 70-75

91. Aaisha G, Barate D (2016) Isolation and Identification of Pectinolytic Bacteria from Soil Samples of Akola Region, India. Intl J Curr Microbiol Appl Sci 5 : 514-521.

92. Simran JK, Vijay KG (2017) Production of Pectinolytic Enzymes Pectinase and Pectin Lyase by Bacillus subtilis SAV-21 in Solid State Fermentation. Annals Microbiol 67: 333-342.

93. Arotupin DJ, Akinyosoye FA, Onifade AK (2008) Purification and Characterization of Pectinmethylesterase from Aspergillus Repens Isolated from Cultivated Soil. African J Biotech 7: 1991-1998.

94. Priya V, Sashi V (2014) Pectinase Enzyme Producing Microorganisms. Intl J Sci Res Pub 4: 1-4.

95. Singh R, Kapoor V, Kumar V (2012) Utilization of Agro-industrial Wastes for the Simultaneous Production of Amylase and Xylanase by Thermophilic Actinomycetes. Braz J Microbiol 43: 1545-1552.

96. Prakash O, Jaiswal N (2009) Alpha-amylase: An Ideal Representative of Thermostable Enzymes. Appl Biochem Biotech 162: 2123-2124.

97. Sundarapandiyan B, Jayalakshmi S (2017) Isolation, Screening and Optimization of Amylase Production by a Marine Bacterium Bacillus Subtilis SJ33. Intl J Adv Res Bio Sci 4: 8-14.

98. de-Souza PM, Magalhães PO (2010) Application of Microbial -Amylase in Industry - A Review. Braz J Microbiol 41: 850-861.

99. Cavalheiro GF, Sanguine IS, Santos FRS, Costa AC, Fernandes M, et al (2017) Catalytic Properties of Amylolytic Enzymes Produced by Gongronella butleri Using Agroindustrial Residues on Solid-State Fermentation. BioMed Res Intl 2017: 1-8.

100. Nwagu TN, Okolo BN (2011) Extracellular Amylase Production of Thermotolerant Fusarium sp. Isolated from Eastern Nigerian soil. Braz Arch Bio Technol 54: 649-658.

101. Sujeeta KM, Shikha M, Khushboo S (2017) Isolation and Screening of Amylase Producing Fungi. Intl J Curr Microbiol Appl Sci 6: 783-788. 